\title{
Leaky Borders and Solid Citizens: Governing Security, Prosperity and Quality of Life in a North American Partnership
}

\author{
Emily Gilbert \\ Canadian Studies and Geography, University College, \\ University of Toronto, Toronto, Ontario, Canada; \\ emily.gilbert@utoronto.ca
}

\begin{abstract}
The Security and Prosperity Partnership of North America (SPP), signed by Canada, Mexico and the United States in March 2005, proposes a dramatic reshaping of the continent. This is no simple plan for the intensification of economic and security cooperation. The SPP is much more expansive and includes quality of life issues such as education, science and technology, the environment, and health. But what does it mean that there is an emergent concern with biopolitics, that is, with the lives and bodies of the region's citizens, at the trilateral level? How are these citizens being imagined in the new regional vision? What are the implications for states and sovereignty? This paper addresses these questions by turning first to the trope of "partnership" as it emerges in the SPP, and then to the ways that borders and population mobility are being construed. The discourse of "partnership" signals a new political rationality that is reconfiguring the relationship between the North American states, their markets and their citizens. The repercussions for citizens and citizenship are especially significant, and are most clearly apparent vis-à-vis border policies, as I discuss in the following section. While external borders are being hardened against most foreign nationals, mobility across internal borders is becoming more differentiated: more penetrable for some, and impassable for others. The SPP thus promotes a divisive and striated regional space that will help perpetuate the ongoing tensions around illegal immigrants and undocumented workers in North America.
\end{abstract}

\section{Introduction}

On 23 March 2005, US President George W. Bush, Mexican President Vicente Fox, and Canadian Prime Minister Paul Martin-dubbed the "three amigos" in the Canadian press-met to discuss the future of North American relations. Over formal deliberations held at Baylor University in Waco, Texas, and then over lunch at President Bush's ranch, the three leaders negotiated a blueprint document, The Security and Prosperity Partnership of North America (SPP). Although brief and bare in details, this was not simply an empty wish list, but a goal-oriented agreement that established Ministerial-led consultative groups to report back on achievable goals within a 90-day frameworkwith the first such progress report issued on 27 June $2005 .{ }^{1}$ The mandate 
of the SPP has also already had an impact on domestic policy; Canada's 2006 budget, for example, allocates an additional Can $\$ 303$ million to border security explicitly to address SPP targets. The principles of and the commitment to the SPP was reaffirmed by all three national leaders (with Canada now being represented by the recently elected Prime Minister, Stephen Harper) when they met again in Cancun, Mexico in March 2006. A second progress report is to be issued by the ministers in June, 2006, and a follow-up meeting between the three federal leaders will be held in Canada in 2007.

While the SPP has been implemented quietly, it is no minor undertaking; it is the most comprehensive trilateral agreement since the North American Free Trade Agreement (NAFTA) of 1993, even if it is without the same kind of legislative backing. It was Mexico and Canada that were most vociferous in the push for a new agreement, faced with grave concerns that US protectionism and unilateralism following the terrorist attacks of 9/11 would interrupt the liberalized movement of people and goods made possible by NAFTA. At the same time, US security concerns at both the Mexican and Canadian borders have made that country more willing to entertain new negotiations that include security matters. Yet while interest in rethinking trilateral relations in the region has been galvanized by the terrorist attacks, the ambition to do so neither originates with this geopolitical event, nor is limited to it (Gilbert 2005). Indeed, as the SPP document makes quite clear, international competitivenessand particularly ongoing growth in Asia, namely China and India-is presented as a key stimulus for renewing the regional vision. The creation of a North American Competitiveness Council as part of the SPP denotes this importance and signals the underlying apprehension about the waning status of North America in the world economy.

Yet the SPP is no simple NAFTA-plus agreement that merely extends free trade, nor it is only about linking economic and security concerns, as with the many "big ideas" that have emerged, especially out of Canada, since 9/11 (Gilbert 2005). Rather, the SPP marks a shift in focus for trilateral relations in that it moves beyond economy and security to include matters such as higher education, science and technology, the environment, and health. As I argue below, this shift in direction signals an emergent concern, at the trilateral level, with the citizens of the three states, with their health, their quality of life, and their freedom. For example, in the SPP document alone, which numbers only a few pages, there are nearly a dozen allusions to "the people", and to their being "protected", "responded to", "invested in" and the promotion of their "full potential". The SPP thus signals a new interest in biopolitics, that is, a concern for the lives and bodies of the population, at the regional level. But it is not that a new kind of regional governance is being envisioned; in fact, the three countries insist that the SPP does not impinge upon their sovereignty. Instead, a model of "partnership" 
that draws upon market-oriented harmonization and convergence will facilitate the seamless regional integration. Very little in the way of state role or infrastructure is envisioned.

In the following section of this paper I provide a more detailed account of the SPP, its shift to biopolitics, and its implications for nation-state sovereignty. I subsequently turn to more carefully examine the ways that the SPP relies on a particular construction of the region's population. Who are the citizens that are being imagined, and even idealized, within this North American political space? How and to what ends is the population managed through the investments in quality of life issues such as health and education? Understanding these questions requires attention to the ways that the SPP reconfigures national and regional borders, with a hardening of external borders while internal borders opened up, albeit only to "legitimate" people and goods. As Matthew Sparke and Davina Bhandar have argued, North American border management increasingly relies upon and reinforces a model of "homo economicus" - a neoliberal citizen who is efficient, productive, and self-maximizing. This "ideal" citizen resonates with the market orientation of the "partnership" agreements. At the same time, the border security measures identified in the SPP, from temporary work agreements to pre-clearance programs, are helping to formalize a hierarchical citizenry, and even the creation of a de facto internal passport.

The official rhetoric of the SPP thus portends a dramatic reshaping of the relationship among North American nation-states, between these nation-states and the market, and with their citizens. Understanding the thrust of this trilateral agreement is thus crucial for coming to terms with the official priorities that underpin key federal initiatives, and for understanding the possibilities for governance that will help shape its future. It is these kinds of questions around the "art of government" that I examine in this paper, drawing upon parallel lines of questioning found in the Foucauldian governmentality literature, and in particular the emergent literature on supra-national governance (eg Dean 1999; Gordon 1991; Larner and Walters 2002, 2004; Rose 2000). The SPP, however, cannot be understood outside of the increasingly virulent on-the-ground politics over borders and border security, and the struggles over immigration policies, which have seen growing public mobilization by undocumented workers. As I will intimate below, these political protests disrupt the seamless regional space evoked by the SPP, and suggest not only alternative conceptions for the future of North America, but also underscore the contradictions that exist within the SPP proposal itself.

\section{A Partnership for Security, Prosperity, and Quality of Life}

The SPP has as its main objectives ensuring that the North American region is safe and secure, that businesses are competitive, and that 
economies are resilient (SPP 2005:1). It aspires to "make North America the best place to live" (Report to Leaders (RL) 2005:24), not only today but "in this and future generations" (SPP 2005:1; emphasis added). It draws upon some more limited statements on bilateral relations, including, for example, the New Partnership of North America signed between Canada and the US, when President Bush made his first state visit to Canada in November 2004. ${ }^{2}$ A month before, Canada and Mexico had signed a parallel joint statement, "A commitment to our common future". ${ }^{3}$ But whereas these bilateral declarations largely address economic issues, with some additional border security measures between Canada and the US, the SPP includes an array of issues such as more cross-border cooperation in some economic sectors, especially autos and steel; the harmonization of external tariffs; more regulatory compatibility for goods and services; more cooperation on energy production, development and security; joint border policies, particularly around pre-clearance programs, biometrics and port security; cooperation and information sharing on law enforcement in matters relating to organized crime, narcotics, firearms and sexual and labour exploitation; collaboration in higher education, science and technology, particularly when it can be instrumental to the above objectives; the development of joint environmental programs towards the protection of biodiversity; and the coordination of a range of health initiatives, eg around infectious diseases and a safe food supply.

The attention to health within this expansive list is particularly notable, and is suggestive of the shifting attention to biopolitical concerns at the trilateral level. Among these include facilitating trade in medical devices; establishing greater market access for natural health products; strengthening and enhancing the exchange of public health information; establishing cross-border support for public health emergencies; and harmonizing pharmaceutical regulation. Detailed proposals are also presented for greater coordination on the surveillance, prevention and control of the spread of infectious diseases such as avian flu, West Nile disease and BSE, with workshops planned to deal with potential plague, Tularemia and smallpox epidemics that could be initiated through bioterrorism. The health of indigenous peoples also receives special mention, with recommendations for health promotion, education, disease prevention and research on and among indigenous peoples. In the Ministerial progress report of June 2005, for example, alcohol abuse and suicide are identified as primary concerns among indigenous peoples. One "key milestone" of SPP success is identified as the creation of a Canada-US website on Suicide Prevention and Fetal Alcohol Spectrum Disorder, and the coordination of a workshop on substance abuse. While the development of workshops and websites is surely a minor undertaking that attends only to the symptoms of aboriginal disenfranchisement rather than to structural causes, their inclusion here effectively demonstrates 
the attention being directed, at the trilateral level, towards the health and bodies of the region's population, and the micro-scale at which these initiatives are being directed.

The breadth of concerns set out in the SPP would appear to bring North America much more in line with the mandate of the European Union (EU), for the Treaty of Rome that signed into place the European Community in 1957 not only set out economic principles, but also included a concern for order, security, public health, safety, and the security of the population-issues that have resurfaced and have been reinforced in recent years (Walters and Haahr 2004:56, 60). As William Walters and Jens Henrik Haahr elaborate, although the EU is itself a site of competing ideologies and programmes, the importance of the Treaty of Rome was that it established certain ideas about how Europe could be governed, certain "possibilities" around governance that have helped shape the region (Walters and Haahr 2004:42). Similarly, while the aims of the SPP are less ambitious than the Treaty of Rome in terms of formal integration, they provide the clearest articulation to date of a government-sanctioned vision for the future of the North American region. And while there are competing and contested visions around this future which will be touched upon below, the SPP provides a foundational framework for how the governance of the region will or can unfold.

What then are the "possibilities" for governance that the SPP reveals? The model that is advanced is one of "partnership", a trope that at once denotes a more market-oriented and market-driven North American region, but also resonates with a particular kind of new US foreign policy. With respect to the market, the term "partnership" signals the increasing congruence with private sector discourse and outcomes (eg increased efficiency), and with the role that the private sector has played in steering the trilateral dialogue. ${ }^{4}$ In October 2004 an Independent Task Force on the Future of North America (ITFFNA) was struck to report, as their name suggests, on the future of the region. Led by three co-chairs, all former high-ranking government officials (now all in the private sector), and three vice-chairs formally representing business-oriented think tanks, the ITFFNA had the blessing of all three governments. ${ }^{5}$ And there has been a considerable iteration between the two reports. The ITFFNA released a preliminary "Chairmen's Statement" in advance of the Waco meetings with the express intent of informing the discussions and encouraging the political leaders to "be bold" in their thinking (Manley et al 2005:8). Published after the meetings, their final report offers specific recommendations, tinged with a sense of "urgency", for how the SPP could be more ambitious (ITFFNA 2005:vii, 1).

The "partnership" at the heart of the SPP also speaks to the inordinate role that the private sector is to play in creating a "seamless market" (ITFFNA 2005:20). Terms such as "cooperation", "collaboration", 
"coordination", and "common approaches" litter the SPP. Underlying this terminology is an agenda of harmonization, not only in terms of the economy-eg around regulations and standards in statistics, motor carrier and rail safety-but also with respect to security and immigration matters, such as the US-Canada agreement on visa waiver countries (SPP 2005:5). As Andrew Barry has written vis-à-vis the EU, harmonization ensures that governance unfolds from the voluntarist and "autonomous economic actions of its subjects" rather than through the creation of a governing transnational state (Barry 1993:315). This bespeaks a political rationality that governs through consent and complicity in ways that will maximize business interests. Each recommendation thus relies upon muted forms of formal political legitimacy and accountability, on the presumption that consensus can be achieved through liberal, but non-governmental negotiation across economic and policy sectors.

But the EU is not a strict template for the North American region. As the ITFFNA makes quite clear: "North America is different from other regions of the world and must find its own cooperative route forward. A new North American community should rely more on the market and less on bureaucracy, more on pragmatic solutions to shared problems than on grand schemes of confederation or union, such as those in Europe. We must retain respect for each other's national sovereignty" (ITFFNA 2005:5; see also Manley et al 2005:8). In keeping with the reluctance to share institutional power in North America, particularly coming from the US (Clarkson 2002), very little in the way of political infrastructure is envisioned in the SPP. ${ }^{6}$ There is no mention of institutional mechanisms to resolve the trade disputes that persist under NAFTA, or for dealing with US-trade remedy practices such as counterveiling and antidumping measures that continue to plague Canada-US relations. Rather, the hundreds of formal treaties and thousands of informal arrangements in existence will be used as building blocks for this managerial vision of regional integration. Instead of a trilateral government, the ITFFNA advocates annual summit meetings for the three political leaders, and perhaps even an interparliamentary exchange. Instead of political representation, a North American Advisory Council could be set up that would comprise non-government representatives who could "provide a public voice for North America" (ITFFNA 2005:32). Finally, it is proposed that regional vision-making could be promoted through private sector Bilderberg- or Wehrkunde-style conferences, perhaps under the auspices of the recently created North American Competitiveness Council (ITFFNA 2005:32). ${ }^{7}$

The SPP thus offers state-directed initiatives but relies heavily upon market players for implementation and guidance. The idea of partnership thus captures the increasing role for the market in this process, but does it also resonate with respect to the unfolding relationship between the 
three countries? Here too the idea of partnership resonates with the kinds of state relations that are envisioned. State relations are to be negotiated through cooperation and collaboration, and precisely because they are presented as outside the sphere of formal governance they are presented as posing little challenge to national sovereignty. Partnership is a concept that enables the presumption of state sovereignty to be retained, and indeed, there are persistent affirmations of "sovereign rights" in the documents, and assertions that deepening integration will not threaten "political and cultural identities" (RL 2005:3). ${ }^{8}$ The language of partnership in the SPP makes sense in that it appeals to a scenario in which all three signatories are active and autonomous players in the evolving North American region (without any requirement that they be equal partners with equal investment or liability); that their actions will be directed towards the best interests of the region (and hence all members of the partnership); and that the outcome-the benefits or profits to be reaped-will be enjoyed by all the signatories. As the ITFFNA spells it out: North America "is a partnership of sovereign states with overlapping economic and security interests, where major developments in one country can and do have a powerful impact upon the other two" (ITFFNA 2005:2).

And yet, there is also an insistence across the SPP and the ITFFNA that the partnership model is possible because of the fundamental values of "liberty", "freedom", and "democracy" that are shared across the region. This is most forcefully evoked on the first page of the SPP where it is remarked that the agreement and its future accomplishments "will reflect our shared belief in freedom, economic opportunity, and strong democratic values and institutions" (SPP 2005:1; emphasis added). This emphasis on shared values persists across other documents as well. The ITFFNA, for example, asserts that: "As liberal democracies, the governments also share common principles: protecting individual rights, upholding the rule of law, and ensuring equality of opportunity for their citizens" (ITFFNA 2005:2; emphasis added). These shared values underscore the common interests of the three countries but also provide a rationale for working more closely on prosperity, security and quality of life. At the same time, they provide justification for the greater investment that will be required for marginalized populations within the region. Mexico, for example, needs to gain greater parity with the US and Canada (a narrowing that was anticipated, but unrealized, under NAFTA), but this is presented as being in the best interests of the region: "Improvements in human capital and physical infrastructure in Mexico, particularly in the center and south of the country, would knit these regions more firmly into the North American economy and are in the economic and security interests of all three countries" (ITFFNA 2005:5). Improvements to quality of life, for example, will help reduce the migration of impoverished Mexicans into the US, and diminish the 
crimes that are lumped in with illegal migration including "corruption, drug trafficking, violence, and human suffering" (ITFFNA 2005:5).

Hence the model of partnership both makes possible a stronger role for the market in the North America region, and provides the rationalization for a strong developmentalist ethos which is rooted in a regional vision. ${ }^{9}$ State aid is to be increased, but made conditional upon regulatory and banking reform and government transparency, conditions that evoke the development policies of the International Monetary Fund and the World Trade Organizations. Market-based foreign investment is also strongly encouraged, to be made possible, for example, through the creation of a North American Investment Fund, and to stimulate growth in the private sphere but also to facilitate investment in public infrastructure in education and health. The underlying premise is that it is only when Mexico becomes self-governing, with similar citizen rights and responsibilities as elsewhere in the region, that it will be an effective and responsible - albeit not necessarily equal-partner in protecting the economic and social security of the region. This neocolonial approach resonates with the health initiatives for indigenous peoples discussed at the beginning of this section-with the attention to disorders such as fetal alcohol syndrome, substance abuse and suicide-and a parallel mandate for internal development. The language used to describe such initiatives is clearly evocative with the policies around Mexico. The Annex to the Ministerial report notes that "In the long run, healthier indigenous peoples and communities will be able to more fully participate in the social, economic and cultural life of North America" (Annex 2005:56). It is thus vis-à-vis marginalized peoples that the techniques of the state and its impress on the lives of its population are most clearly visible.

The "partnership" model proposed by the SPP clearly resonates in many ways with the mandate of "partnership" that had seeped into US foreign policy. Colin Powell, writing in his capacity of US Secretary of State in Foreign Affairs, identified "A strategy of partnerships" as a cornerstone of contemporary US foreign policy, alongside and complementary to the war on terrorism and preemptive war (Powell 2004). ${ }^{10}$ The objective is to establish partnerships not just with traditional friends and allies, but also, and perhaps especially, with former adversaries such as Russia, India and China (National Security Strategy 2002). ${ }^{11}$ These partnerships will enable the advancement of common strategic interests, from trade to anti-terrorism. Moreover, shared values of "freedom and dignity" will be affirmed, including "the rule of law; limits on the absolute power of the state; free speech; freedom of worship; equal justice; respect for women; religious and ethnic tolerance; and respect for private property" (Powell, 2004). Hence, Powell argues, the model of partnership presents a holistic approach to foreign policy that is infused with moral values. 
The SPP clearly resonates with this mandate of partnership building to reinforce common interests and allegiances for the US. What sets the SPP apart from the broader US foreign policy, however, is the explicit appeal to the citizens of North America, the emphasis on matters pertaining to quality of life, and the micro-scale at which these citizens and their quality of life are to be managed and promoted. To use the words of Prime Minister Martin, the SPP "is not a geopolitical agenda. It's a people's agenda". ${ }^{12}$ The welfarist approaches to regional development are not simply presented as geopolitical strategy, but as being in the best interest of each and all citizens of North America. And this attempt to at once individualize and totalize the value of its recommendations (cf Gordon 1991:26), so that they speak both to the interests of each citizen but also the citizenry of the region as a whole, reinforces still further that there is an emergent trilateral political rationality in the SPP that is being advocated and justified through an appeal to the region's population. "Quality of life" and the shared values of "liberty," "freedom," and "democracy" become the premises for governance, but are also objectives that endow these projects with legitimacy. In turn, these values make possible a more intensive and intrusive trilateralism, which in turn enables the mobilization of the "freedoms, choices, and desires of [the state's] subjects" (Walters and Haahr 2004:119).

As with much state-making, sovereignty is often cast as the ultimate state apparatus of the modern western state - through which states have conventionally sought to limit and rationalize themselves, largely by demonstrating the security of their borders (Brown 1995:17). Yet states are neither simply, nor even mainly, concerned with sovereignty. Rather, as Mitchell Dean explains, drawing upon Michel Foucault, modern forms of authority - typified by geopolitical forms such as the stateare hinged around three lineages of power: "sovereignty-disciplinegovernment" (Dean 1999:20). This tripartite formula suggests that liberal states revolve around a series of interests that include sovereigntyand which involves the defence and security of the population contained within its legally and politically defined territory-but also the disciplining and regulation of subjects into docile citizens, and the optimization of subjects through the governing of life and the economy (Dean 1999:104). At the heart of the liberal state is thus a concern for the lives of its subjects, for the management of its citizens. This interiorization of the state both explains and rationalizes why governments have sought to articulate their mandates in terms of "for each and for all", and how in turn their performance has come to be assessed in terms of their ability to ascertain the "the health, welfare, prosperity and happiness of the population" (Dean 1999:19).

What is new and noteworthy in the North American context is that it is precisely these characteristics - health, welfare, prosperity, happinessthat underpin the SPP. The SPP thus signals a concern not just for 
economic liberalization, as is found in NAFTA, but also a concern for biopolitics, that is, an interest in the lives and bodies of the population. Inasmuch, the partnership manifests examples of, at the transnational level, a particular form of governmentality, or a regime of government, which is usually associated with the western, liberal nation-state. Yet is this really a smooth, seamless regional space that is being imagined into being? How do the border and security concerns reconcile with this idealized vision of regional integration? For is it not simply that the transnational scale is supplanting the national. The state has not disappeared, nor is it becoming irrelevant. Nor are the citizens that are being appealed to explicitly elided into a single, territorialized population to be managed by some form of trilateral government. Rather, there is a hierarchization of citizens and citizenship implicit within the SPP that presents quite a different understanding of the unfolding regional space. In the following section I turn to examine how citizenship is constituted through the SPP, and idealized "in ways which seek to elicit agency, enhance performance, celebrate excellence, promote enterprise, foster competition and harness its energies" (Walters and Haahr 2004:119). The maximization of individuals so that they are able to self-govern is presented as making the ideals of "liberty" and "freedom" realizable, but it is also through this construction of citizenship that the population is differentiated and through which discrimination takes place.

\section{Leaky Borders and Solid Citizens}

If the SPP is promoting a smoother, more seamless economic and security space, what does the future hold for the national borders in the region? Addressing this question demands attention to the question of citizenship. For borders, and their changing role and function, offer a valuable means for understanding the shifting contours of citizenship and its relationship to the state. Conventionally, national borders have been used to delimit and define the territorial boundaries of states-and establish their integrity and sovereignty-but also to demarcate which populations are to be governed and who is to be excluded. Hence they are usually subject to high forms of security and surveillance precisely because they are used to regulating national entitlements around the right to life, health, security and prosperity. The border thus operates as an order of subjectification that, as Michael Dillon remarks, has as its objective the production of "calculable subjects operating in calculable spaces" for whom their subjectification (or their constraint within particular kinds of borders) is the very basis for their freedom and their empowerment (the entitlements, the belonging that they achieve within that border) (Dillon 1995:324).

The importance of attending to borders here is that the SPP augurs a significant redrawing of North America that will significantly impact 
upon the mobility of the population across the region. Essentially, the SPP draws upon a number of recent bilateral agreements-which as we will see have opened up the borders to particular kinds of people while closing them against others-but moves beyond them towards a single, external North American border, portending what some have dubbed a "Fortress North America". Among the SPP recommendations are for the three countries to establish a coordinated system to prescreen foreigners (and goods) before first port of entry in North America; to share bioprotection strategies to regulate this movement; to further coordinate land, maritime and aviation security across the continent; to further coordinate the prevention of and emergency response to threats; and to build intelligence partnerships to monitor internal and international threats. The ITFFNA takes these ideas still further in that they recommend a common security perimeter in place by 2010; a unified border action plan; deepening and expanding military and intelligence programs, including NORAD; and even the creation of a North American Border Pass.

This hardening of external borders parallels developments in the European Union. In 1985, the Schengen agreement was signed by nine members of the European Union who were "committed to establishing common external border controls, abolishing internal controls between member states, and to introducing a shared computer database on asylum seekers, illegal immigrants, and people with police criminal records" (Dillon 1995:367). By 1999, the principles of this agreement were taken on more broadly, creating a particular regime of security and mobility that Walters and Haahr call, after the original 1985 agreement, "Schengenland" (Walters and Haahr 2005:92). This resulted in both a hardened external border, but also the receding of importance of internal barriers (Walters 2002:573; but see Balibar 2004). The external border was reinforced by some of the shared EU practices associated with Schengenland, such as common visa policies, safe third country agreements, and coordinated border management and information exchange-policies that are echoed in the SPP. With respect to internal borders they were becoming less impenetrable as the citizens of other signatories were being treated the same way a nation-state would treat its own nationals. ${ }^{13}$ Moreover, as Walters documents, security concerns were displaced away from internal borders-internalized across the domestic territory so that they become ubiquitous, but also exteriorized onto the private sector (eg airline carriers) and extra-territorially (eg by extending pre-clearance practices onto foreign consulates) (Walters 2002:574; Walters 2004b:251; Bigo 1994). Likewise, the diffusion of security away from internal borders is an important component of the SPP, which proposes that the three governments "commit themselves to the long-term goal of dramatically diminishing the need for the current intensity of the governments' physical control of traffic, travel and 
trade within North America" (Manley et al 2005:12; emphasis in the original).

Yet, despite the obvious parallels with the EU, there are considerable differences. While surveillance and security concerns are being dispersed away from the border and internalized across the regional territory, and while the security and economic concerns of the regional space are being smoothened out through policies of harmonization and development, internal barriers to mobility are not being erased. If anything, constraints to North American border mobility have been amplified. The US government's Western Hemisphere Travel Initiative of 2004 requires that all travellers crossing its border, US citizens and non-citizens alike, carry passports or their equivalent, a policy that has generated significant consternation in Canada as it depends on easy mobility for trade and tourism, with over 200 million people crossing the border annually. ${ }^{14}$ The securitization of the borders has also increased, with triple the number of border agents at work on the Canada-US border since 9/11. These 1000 agents are still significantly lower than the 10,000 border patrol agents at the US-Mexico border-which is half as long-who have been supplemented recently by the National Guard. Vigilante armed patrols such as the Minutemen, counting 6500 volunteers nationwide, have been set up at sites along the US-Mexico border to defend against illegal crossing, and chapters have even ventured to the US's northern border. ${ }^{15}$ Mexico has also sought to reinforce its own border; "Operation Secure Mexico" was launched in June 2005 to target drug cartels, with particular attention to security concerns around the northern border, but there is also increasing securitization at the southern border to prevent illegal immigration from Latin America. And bills have been approved in both the US House of Representatives and Senate to build additional fences across key border crossings with Mexico, with the Department of Homeland Security mandated to study the feasibility of a fence along the US-Canada border. ${ }^{16}$

At the same time that borders are being hardened, however, the SPP seeks to "streamline the secure and efficient movement of legitimate, low-risk traffic across our shared borders" (SPP 2005:1; emphasis added). The SPP devotes some attention to facilitating the mobility of manual labourers, but only under highly regulated temporary worker programs such as those for seasonal, Mexican agricultural labour in Canada (Basok 2002) ${ }^{17}$ There exists much greater interest, however, in the expansion of pre-clearance programs. As Matthew Sparke describes vis-à-vis the rise of the trans-border Cascadia region, Canada and the US introduced separate pre-clearance programs for "managerial class elites" in the 1990s (Sparke 2004; 2005). In the wake of 9/11, these programs were formally harmonized into joint-border programs such as FAST (Free and Secure Trade) and NEXUS with the signing of the Smart Border Declaration and 30-point Action Plan on 12 December 2001. ${ }^{18}$ 
Three months later a similar agreement was signed between the US and Mexico, with one of its aims the expansion of the parallel pre-clearance program called Secure Electronic Network Travelers' Rapid Inspection (SENTRI) ${ }^{19}$ Security checks are undertaken of all applicants, who pay a minimal fee for a five-year clearance pass, with their personal information then stored in joint security databases accessible to government and law-enforcement agencies. Participants in the pre-clearance programs have dedicated lanes at some land crossings - with marine and air pilot projects under way- that enable them to circumvent regular checks by customs and immigration. ${ }^{20}$

The SPP emphasizes the importance of pre-clearance programs and the ability of participants to capitalize on what Aihwa Ong calls "flexible citizenship" (Ong 1999:7). Ong uses the figure of "homo economicus", as it is revived by Foucault, to evoke this new type of "citizen hero" who is able to act "an entrepreneur of him- or herself" and to "optimize" his or her skills in a trans-national arena (Ong 2004:56; Rose 2000:162). This typology has already been deftly used by Sparke and Davina Bhandar to explain the ongoing reconfigurations of the Canada-US border (Sparke 2004, 2005; Bhandar 2004). Citizens gain preferential mobility rights when they are able "to conduct themselves in the most beneficial ways to their health, wealth and happiness in ways that are rational, self-interested and calculating"- a description that neatly evokes the mandate of the SPP (Isin 2004:220). Compliance is thus central to privileged mobility. But moreover, rational behaviour is construed as moral behaviour, with those who are able to rationalize their actions in terms of "costs, benefits and consequences" being validated as "citizen heroes"an eliding of rationality and morality that is particularly potent under the moral aegis of the War on Terror (Brown 2003:sections 9, 15; Lemke 2001:201).

Foucault suggests that the model of "homo economicus" is the "central point of reference and support" of neoliberalism which "locates the rational principle for regulating and limiting the action of government ... in the entrepreneurial and competitive behaviour of economic-rational individuals" (Lemke 2001:200). Governments become "a sort of enterprise", writes Thomas Lemke, that "develop indirect techniques for leading and controlling individuals without at the same time being responsible for them" (Lemke 2001:197, 201). And it is here that we can return to the discourse of partnership that is used to characterize the new North American arrangements, for this discourse not only frames how the relationship between the three signatory states and their markets are to be understood, but how these states are to govern in this entrepreneurial spirit vis-à-vis their own populations. As we have seen above, the SPP and ITFFNA advocate policies of harmonization and development to help certain populations - eg Mexicans, indigenous peoples- to become self-maximizing. More generally, the SPP aims "To better prepare our 
people to deal with the challenges of the knowledge-based economy ... [our aim] is to empower our people through enhanced higher education, academic exchanges, and common research and development initiatives, so as to better prepare our human capital for the future" (RL 2005:2324). "Homo economicus" is thus both the target outcome of governance but also an idealized citizen-subject - autonomous, entrepreneurial, and responsible; the success of these citizens in turn provides the rationalization for the state's ability to govern in the name of "liberty", "freedom" and "democracy".

But there is a shadow figure to "homo economicus". There are those who are deemed unable to manage themselves in "rational" and "moral" ways - those who are not compliant- these people are the new undesirables. As Nikolas Rose remarks, writing before 9/11, "An image takes shape — often racialized and biologized — of a permanent underclass of risky persons who exist outside the normal circuits of civility and control and will therefore require permanent and authoritarian management in the name of securing a community against risks to its contentment and its pursuit of self-actualization" (Rose 2000:164). The SPP is vague about who counts as a risky person, but the potential threats posed by terrorists, drug users and smugglers, illegal immigrants, and other criminals are highlighted, who are all strung together as if related along a kind of "security continuum" (Bigo 1994:164; SPP 2005:3; see also Walters 2004b). We see, however, in the post 9/11 era, an increase in racialization and biologization with the racial profiling of "risky" communities, particularly Muslims and those believed to be of Arab descent. ${ }^{21}$ The fixing of identity in terms of biological markers or biometrics to ascertain the legitimacy of travellers-from passports to NEXUS cards to proposed national identity cards - also has the potential to contribute to these processes. ${ }^{22}$ All such state identity documents involve the imposition of some kind of "durable identity" through which states "achieve their administrative, economic and political aims", which also serve to inculcate normative, state-sanctioned identities-race being one such identity (Torpey 2000:166). Biometrics fix people in particular kinds of identities that are reducible to the body, yet the special trick that they perform is that they obfuscate the very embodied dimensions of their classification by turning instead upon languages of authenticity and inauthenticity (see Muller 2004). So while the body is used to fix an identity, the racialization and biologization of these discourses is obscured.

The SPP hence does not simply promise a smooth and seamless regional space but one that is hierarchically differentiated along the lines of citizenship, largely construed through mobility rights as the border is being reconfigured. The expansion of temporary work programs would simply replicate neo-colonial development in that it encourages dependency on cheap and vulnerable extra-national labour, with no promise of full or even partial citizenship rights. The NEXUS and SENTRI 
programs, with their pre-clearance protocol and biometric signifiers, enable easy mobility but only for those compliant participants who are self-maximizing and self-regulating. The SPP is thus no idealized Schengenland in which national borders are effaced. Rather, the proposed expansion of NEXUS and SENTRI passes is evocative of the internal passes associated with the authoritarian governments in South Africa and the Soviet Union. There, passes sought to limit and restrict the movement and residential options of the majority of the population-blacks and rural dwellers - as a mechanism for facilitating particular kinds of economic restructuring, and "for discriminating among its subjects in terms of rights and privileges" (Torpey 2000:165; Garcelon 2001; Lyon 2001). In North America, by contrast, special passes provide advantages to their bearers who are able to maximize themselves in the more integrated regional economy that is touted as being at the very heart of the SPP. In other words, those without passes do not gain preferential mobility and hence cannot maximize their potential in "Fortress North America".

Yet although the principles of the SPP have been agreed to by the governments of Mexico, Canada and the United States, this does not mean that they are uncontested. The recent rash of protests around illegal immigrants and undocumented workers has not had the SPP as its explicit target, what is at stake are the very kinds of discriminatory practices around mobility that have been described above. The "Day without Immigrants" of Monday 1 May 2006 was triggered by HR 4437, the House of Representatives bill (colloquially known as the "Sensenbrenner bill") that would tighten security measures against illegal immigrants, criminalize those who assist them, and erect fences across the US-Mexico border. Over a million people publicly demonstrated their support for the role of undocumented workers in the US economy by not working, not going to school and attending rallies, and estimates are that a much greater number participated in some way in these protests. ${ }^{23}$ Notably, much of the protest was framed in terms of affirming the place of illegal immigrants in the US, with the president of the National Capital Immigration Coalition in Washington DC proclaiming, "Today we march. Tomorrow we vote". US flags were much in evidence, and a Spanish version of The Star Spangled Banner, called Neutro Himno, had even been prepared in advance. ${ }^{24}$ Questions of belonging and of claims to citizenship have also reared their head in Canada, especially since the heartless practices around deportation have been publicized. A particularly poignant incident in Toronto was when two young children of illegal immigrants were detained by authorities after school so that their parents could be apprehended. This incident was among a number of public cases that thrust questions of illegal immigrants and undocumented workers into the spotlight and have led to a series of well-attended demonstrations. These examples, just two of any number 
of ongoing mobilization, speak to the simmering tensions that the hierarchies of citizenship mobility have helped to generate, and that the SPP with its differentiation of border mobility can only help to perpetuate.

\section{Conclusions}

The continentalist vision of the SPP presents a new way of thinking about trilateral governance in the North American region. Ideas of citizenship and territoriality are being reworked as a new kind of dance is being played out between nation-states and their trilateral commitments (cf Walters 2004b). Biopolitical concerns are being articulated at the trilateral level, but nation-states continue to demonstrate an interest in managing the lives and bodies of their citizens and presume the authority to do so. Yet the role of the state is changing, and the context in which it operates has shifted, although it has certainly not disappeared. In this sense the SPP is very much in keeping with what Wendy Larner and William Walters have called the "new regionalism," a new kind of internationalized government that has emerged since the 1970s to deal with an increasingly global and market-driven economy (Larner and Walters 2002:408). Regional alliances can be understood, they argue, "as a collective response, a way in which states can win back some control over otherwise undisciplined economic and social forces" (Larner and Walters 2002:409). The partnership model of the SPP captures this model of "new regionalism". The state is conceived of as an "enterprise", competitive in the global economy, and working together with the other signatory states within the region, but ostensibly autonomous. The model of governance is limited, operates at a distance, and is designed to remove obstacles to the liberalization of the individuals, states and markets through the harmonization, cooperation and the voluntarism of participants from government, market, and business (Larner and Walters 2002:414, 416).

Yet, there is also within the SPP a much more expansive regional vision that is concerned with maximizing citizen quality of life and managing the population by attending to micro-scale concerns for health and education. The emergent concern with the biopolitics of the region's population is legitimated through an insistence on the shared values of freedom, liberty and democracy that are said to draw the region together. In turn these shared values are used to mobilize particular neoliberal and developmentalist agendas. For example, the betterment of marginalized peoples, whether Mexicans or indigenous peoples, is presented as being in the interests of each and all in the region. This denotes an emergent trilateral concern for sovereignty, discipline and government that is more evocative of the regional intensity that has developed in Western Europe. In the North American context, however, little political infrastructure is proposed to mediate investment or economic development. Rather, these 
are to be market-driven initiatives with market-driven objects. Paradoxically, the SPP offers little in the way of representation, participation and accountability, cornerstones of the very democratic principles that the SPP evokes.

There is thus a significant disconnect between the ideals that the SPP proposes - a smooth and seamless economic space embedded in liberty, freedom and democracy - and the practices that it makes possible. Not only is there little avenue for public engagement in the unfolding continental vision, but the reconfiguration of the borders that the SPP augurs depends upon differentiated mobility rights across the region. External borders are to be hardened around the "Fortress North America", but internal borders are also to become increasingly securitized, except to "legitimate" travellers. These self-regulating and selfmaximizing individuals - the "homo economicus"-are both the exception and the ideal. Their preferential mobility is being formalized through pre-clearance protocols around risk assessment and surveillance. Compliance with these programs is rewarded with almost limitless mobility which enables these elites to capitalize upon the integrating regional economy. By contrast, manual labourers are constrained by temporary worker programs that are largely designed to foreclose full citizenship opportunities. The marginalized, the dispossessed, and the unemployed have no opportunities for mobility, and are to remain very much fixed in place where they are.

To regulate this mobility there is an increasing reliance on biometric identifiers. Policy documents assert the importance of biometrics to ensuring border security, and travel documents from passports to preclearance passes are being inscribed with biometric information. As Bhandar astutely observes, a problem with biometrics is that they fix human life that is otherwise in flux, "of creating 'stability' in a life that is unstable" (Bhandar 2004:275). Hence, in the unrelenting liberalization of the North American economic space we have not simply the opening up of markets and economies but a coterminous fixing of people in place, and in terms of particular identity formations. As Foucault has insisted, however, being human "always already exceeds the categories that are employed to define and control" (Dillon 1995:327). In other words, the tools of subjectification can also become the tools used by the subjugated to articulate their opposition. With respect to identity documents, for example, Jane Caplan and John Torpey suggest that while state-sanctioned identities can conscribe, they have also been used as the platform from which minority individuals and populations have launched collective claims against the authorities (Caplan and Torpey 2001:6). The increasingly visible and resilient protests against the toughening of citizenship and immigration policies in North America since 9/11 also point to sites of opposition, and the public dimensions into which these debates around migration and mobility are being 
propelled, precisely as public rights of citizenship are being curtailed. Yet this potential for refusing these fixed forms of identification, categorization and mobility does not offset the hierarchical space that is reinforced by the SPP. This template for regional governance does not just offer a smooth and seamless economic and security space, but one fraught with "lines of stratification-associated with the lines of capital, value and labor flows-[that] are layering the possibilities and conditions of citizenship achievement, a structuring of life chances according to one's specific location in the new geographies of production. Market forces are assigning people different kinds of fate, lines of differentiation by skill and occupation that are continuous across national borders" (Ong 2004:66-67). In the North American partnership that it unfolding, citizens are intended to be anything but equal partners.

\section{Acknowledgements}

Many thanks to the three reviewers and to the editor Noel Castree for their thoughtful and attentive comments which have helped me to sharpen and open up my arguments. The usual disclaimers apply.

\section{Endnotes}

${ }^{1}$ The report details progress to date-an agreement on electronic commerce, liberalization of rules of origin for certain goods, etc-as well as concrete proposals, such as the development of a trilateral Regulatory Cooperation Framework by 2007. Notably, the Ministers involved from each country are high-ranking officials, including Michael Chertoff, Secretary of Homeland Security, and Condoleezza Rice, Secretary of State for the US. See the Government of Canada website http://www.fac-aec.gc.ca/spp/sppmenu-en.asp (last accessed 1 June 2006).

2 See the White House website: http://www.whitehouse.gov/news/releases/2004/11/ 20041130-3.html (last accessed 6 June 2006).

${ }^{3}$ Press release available on the Embassy of Mexico in Canada website: http://www. embamexcan.com/PRESS/Press2004/ComOct25-2-EN.shtml (last accessed 1 June 2006).

${ }^{4}$ See, for example, the 2004 report of the Canadian Council of Chief Executives (CCCE), New Frontiers: Building a 21st Century Canada-United States Partnership in North America, and the US-Mexico "Partnership for Prosperity" agreement signed in March 2002.

5 The three think tanks are the Council on Foreign Relations, the Canadian Council of Chief Executives, and the Consejo Mexicano de Asuntos Internationales. Biographical information on the key players is available at http://www.cfr.org/ publication.html?id=8102 (last accessed 1 June 2006).

${ }^{6}$ For many in North America, the European model is far too integrationist and bureaucratic, despite widespread criticisms regarding lack of democratic representation and accountability. North American state formation, with its more recent nineteenthand twentieth-century evolution, is significantly different from that of Europe. The specificities of these narratives cannot be dealt with adequately here. Clarkson (2002) addresses the differences in governance in US and Canada; regional analysis such as DePalma (2001), Earle and Wirth (1995) and Inglehart, Nevitte and Basañez (1996) offer further insights. 
7 The annual Bilderberg and Wehrkunde conferences deal with economic, political and military issues. They are attended by the political and business elite of North America and Europe, but their proceedings are shrouded in secrecy and for this have been subject to a significant amount of criticism. The North America Competitiveness Council typifies this kind of private sector involvement; it comprises 10 senior private sector representatives from each country who will be consulted on the SPP mandates.

${ }^{8}$ That the opposition to the SPP in all three countries, on the right or the left- - whether by Representative Tom Tancredo (R-Colo) and the Minutemen, or the Council of Canadians and the Partido de la Revolucion Democratica in Mexico-is mobilizing around the language and logic of sovereignty speaks to the potency of the claims to autonomy and independence.

${ }^{9}$ Cristina Rojas reminds us that foreign aid and then foreign development have been, since the Cold War, the most effective non-military mechanisms used for international geo-political influence, geared first towards economic and then population improvement, and used especially by the US (Rojas 2004:100-101).

${ }^{10}$ Since its formation, there has been a tradition of US Secretaries of State writing key policy pronouncements in Foreign Affairs. George F Kennan's piece, "Long telegram”, for example, announced the Cold War doctrine of containment.

11 US National Security Strategy (2002) available at http://www.whitehouse.gov/ nsc/nss.pdf (last accessed 1 June 2006).

12 Then Prime Minister Paul Martin was speaking to the Economic Club of New York, 6 October 2005. Speech available at http://www.pm.gc.ca/eng/news.asp?id=603 (last accessed 1 June 2005).

${ }^{13}$ This is not to suggest that discrimination has been eradicated. While EU citizens might have become more accepted across the region, non-nationals such as refugees, asylum seekers and migrant workers have become more obvious targets of prejudice (Walters 2004a:168; see also Balibar 2004; Dillon 1995).

${ }^{14}$ By 1 January 2007 passports or their equivalent will be required at all CanadaUS air and sea crossings, and at land crossings by 1 January 2008. Canada has been pushing for a delay in implementation, as have representatives from US border states, both Republicans and Democrats, because of the importance of cross-border trade and tourism.

${ }^{15}$ It is worth nothing that there are also groups such as border Samaritans and No More Deaths who provide humanitarian assistance to those attempting to cross the border.

${ }^{16}$ Estimates are that 4 million illegally cross the US-Mexico border annually, with 25-30\% caught and deported. Reported deaths at the border are also on the increase, with about 500 in 2005. While concerns about illegal immigration are not quite as heated along the 49th parallel, Canada continues to be blamed for harboring terrorists. The Country Reports on Terrorism 2005 criticizes Canada's "liberal immigration and asylum policies" that have allowed terrorists "to enjoy safe haven, raise funds, arrange logistical support, and plan terrorist attacks" and is disparaging about domestic anti-terror legislation (p 160). Available on the US Department of State website: http://www.state.gov/s/ct/rls/crt/c17689.htm (last accessed 1 June 2006).

17 There have been ongoing discussions between Canada and Mexico to expand the temporary worker programs beyond agriculture into construction work, and some bluecollar work in the service industry (fast food and restaurants). Fox made this a priority in Canada-Mexico discussions leading up to Cancun. About 7200 Mexican agricultural workers work on Ontario farms; with a consulate opened in the agricultural capital Leamington, ON (population 30000). Basok (2002) has written extensively on the exploitation of these workers, and their limited access to social welfare - to which they contribute - and to citizenship rights (see also Abu-Laban and Gabriel 2002).

18 That the Smart Border Agreement could be signed so quickly into place after $9 / 11$ was partly because discussions had already been initiated to harmonize 
the separate programs, with the first joint NEXUS program launched in the fall of 2000.

${ }^{19}$ The US-Mexico Border Partnership Agreement with 22-Point Action Plan is available at http://www.state.gov/p/wha/rls/fs/8909.htm. The SENTRI program has about 76,000 registered participants, and is operational in the states of California, Arizona and Texas.

${ }^{20}$ Eleven NEXUS border crossing points are currently open, with two more in the planning; 76,000 individuals and 54,000 truckers have been approved for a 5-year period. The October 2004 update on the Smart Border Accord reports on the success of joint operations in removing 898 people from the two countries since 9/11.

21 See, for example, "Impacts on Arab and Muslim Community in Canada", Anti-Terrorism and the Security Agenda: Impact on Rights, Freedom and Democracy" public forum, 17 February 2004, available at http://www.interpares.ca/en/ publications/pdf/ICLMG.pdf (last accessed 1 June 2006).

22 The US PATRIOT act and the US-VISIT program both assert the importance of biometrics to "facilitating legitimate travel and trade across our borders" (emphasis added). See the US Homeland Security website http://www.dhs.gov/ dhspublic/interapp/content_multi_image/content_multi_image_0006.xml.

${ }^{23}$ The number of illegal immigrants in the US is estimated at about 11 million, comprising $5 \%$ of the workforce (numbers that are much higher in some sectors such as agriculture and construction).

${ }^{24}$ The Spanish translation of the US national anthem raised great consternation and on 18 May the Senate voted to make English the "national language" of the US and to work towards conserving English as the nation's primary language.

\section{References}

Abu-Laban Y and Gabriel C (2002) Selling Diversity: Immigration, Multiculturalism, Employment Equity and Globalization. Peterbrorough: Broadview Books

Annex (2005) Security and Prosperity Partnership of North America, Report to Leaders. http://www.fac-aec.gc.ca/spp/spp-en.pdf (last accessed 1 June 2006)

Balibar E (2004) We, the People of Europe? Reflections on Transnational Citizenship. Princeton: Princeton University Press

Barry A (1993) The European Community and European government: Harmonization, mobility and space. Economy and Society 22(3):314-326

Basok T (2002) Tortillas and tomatoes: Transmigrant Mexican harvesters in Canada. Montreal and Kingston: McGill-Queen's University Press

Bhandar D (2004) Renormalizing citizenship and life in Fortress North America. Citizenship Studies 8(3):261-278

Bigo D (1994) The European internal security field: Stakes and rivalries in a newly developing area of police intervention. In $\mathrm{M}$ Anderson and $\mathrm{M}$ den Boer (eds) Policing Across National Boundaries (pp 161-173). London and New York: Pinter Publishers

Brown W (1995) States of Injury: Power and Freedom in Late Modernity. Princeton: Princeton University Press

Brown W (2003) Neo-liberalism and the end of liberal democracy. Theory and Event. http://muse.jhu.edu/journals/theory_and_event/v007/7.1brown.html (last accessed 1 June 2006)

Canadian Council of Chief Executives (CCCE) (2004) New frontiers: Building a 21st century Canada-United States partnership in North America; April

Caplan J and Torpey J (eds) (2001) Documenting Individual Identity: The Development of State Practices in the Modern World. Princeton and Oxford: Princeton University Press 
Clarkson S (2002) Uncle Sam and US: Globalization, Neoconservatism, and the Canadian State. Toronto: University of Toronto Press

Dean M (1999) Governmentality: Power and Rule in Modern Society. London: Sage Publications

DePalma A (2001) Here: A Biography of the New American Continent. New York: Public Affairs

Dillon M (1995) Sovereignty and governmentality: from the problematics of the "new world order" to the ethical problematic of the world order. Alternatives 20: 323-368

Earle R L and Wirth J D (eds) (1995) Identities in North America: The Search for Community. Stanford: Stanford University Press

Garcelon M (2001) Colonizing the subject: the genealogy and legacy of the Soviet internal passport. In J Caplan and J Torpey (eds) Documenting Individual Identity: The Development of State Practices in the Modern World ( $\mathrm{pp} 83-100)$. Princeton and Oxford: Princeton University Press.

Gilbert E (2005) The inevitability of integration? Neoliberal discourse and the proposals for a new North American economic space after 9/11. Annals of the Association of American Geographers 95(1):202-222

Gordon C (1991) Governmental rationality: An introduction. In G Burchell, C Gordon and P Miller (eds) The Foucault Effect: Studies in Governmentality (pp 1-51). Chicago: The University of Chicago Press

Independent Task Force on the Future of North America (ITFFNA) (2005) Building a North American Community. http://www.cfr.org/publication/8102/ (last accessed 1 June 2006)

Inglehart R, Nevitte N and Basañez M (1996) The North American Trajectory: Cultural, Economic and Political Ties among the United States, Canada and Mexico. New York: Aldine de Gruyter

Isin E (2004) The neurotic citizen. Citizenship Studies 8(3):217-235

Larner W and Walters W (2002) The political rationality of "new regionalism": Towards a genealogy of the region. Theory and Society 31:391-432

Larner W and Walters W (eds) (2004) Global Governmentality: Governing International Spaces. London and New York: Routledge

Lemke T (2001) The birth of bio-politics: Michel Foucault's lecture at the Collège de France on neo-liberal governmentality. Economy and Society 30(2):190-207

Lyon D (2001) Under my skin: From identification papers to body surveillance. In J Caplan and J Torpey (eds) Documenting Individual Identity: The Development of State Practices in the Modern World (pp 291-310). Princeton: Princeton University Press

Manley J P, Aspe P and Weld W F (2005) Creating a North American Community. Chairmen's Statement, Independent Task Force on the Future of North America, sponsored by the Council on Foreign Relations, with the Consejo Mexicano de Asuntos Internacionales and the Canadian Council of Chief Executives:1-15. http://www.cfr. org/publication/7912/creating_a_north_american_community_chairmens_statement. html (last accessed 1 June 2006)

Muller B J (2004) (Dis)qualified bodies: Securitization, citizenship and "identity management". Citizenship Studies 8(3):279-284

Ong A (1999) Flexible Citizenship: The Cultural Logics of Transnationality. Durham NC: Duke University Press

Ong A (2004) Latitudes of citizenship: Membership, meaning, and multiculturalism. In A Brysk and G Shafir (eds) People Out of Place: Globalization, Human Rights, and the Citizenship Gap (pp 53-70). New York and London: Routledge

Powell C L (2004) A strategy of partnerships. Foreign Affairs January/February

Report to Leaders (RL) (2005) Security and Prosperity Partnership of North America. 
http://www.spp.gov/report_to_leaders/Trilingual_Report_to_Leaders.pdf?dName/ report_to_leaders (last accessed 1 June 2006)

Rojas C (2004) Governing through the social: Representations of poverty and global governmentality. In W Larner and W Walters (eds) Global Governmentality: Governing International Spaces (pp 97-115). London and New York: Routledge

Rose N (2000) Governing liberty. In R V Ericson and N Stehr (eds) Governing Modern Societies (pp 141-176). Toronto: University of Toronto Press

Security and Prosperity Partnership of North America (SPP) (2005) http://www.facaec.gc.ca/spp/spp-menu-en.asp (last accessed 1 June 2006)

Sparke M (2004) Passports into credit cards: On the borders and spaces of neoliberal citizenship. In J S Migdal (ed) Boundaries and Belonging: States and Societies in the Struggle to Shape Identities and Local Practices. Cambridge: Cambridge University Press

Sparke M (2005) A neoliberal nexus: Economy, security and the biopolitics of citizenship on the border. Political Geography 25(2):151-180

Torpey J (2000) The Invention of the Passport: Surveillance, Citizenship and the State. Cambridge: Cambridge University Press

Walters W (2002) Mapping Schengenland: Depoliticizing the border. Environment and Planning D: Society and Space 20:561-580

Walters W (2004a) The political rationality of European integration. In W Larner and W Walters (eds) Global Governmentality: Governing International Spaces (pp 155173). London and New York: Routledge

Walters W (2004b) Secure borders, safe haven, domopolitics. Citizenship Studies $8(3): 237-260$

Walters W and Henrik Haahr J (2004) Governing Europe: Discourse, Governmentality and European Integration. London and New York: Routledge 